\title{
The Role of Technology and Social Media In Spreading the Quran and Hadith by Mubalig
}

\author{
Mohammad Hidayaturrahman \\ Wiraraja University \\ email: hidayaturrahman@wiraraja.ac.id
}

\section{D.I. Ansusa Putra}

State Islamic University Sulthan Thaha Saifuddin

email: ansusa@uinjambi.ac.id

\begin{abstract}
:
This research was conducted to find out how the role of technology and social media in spreading Al-Quran and hadith by the mubalig. This research used qualitative descriptive approach, while the method of collecting the data was observation on the activities of the mubalig and dai who perform religious da'wa activities, both in mosques, langgar, and majlis taklim assemblies held at homes of pilgrims or mubalig house. This research found that, mubalig already using technology and social media for the purposes of their da'wa. The preachers use technology and social media for various purposes of da'wa, communicating with the congregation of recitation, to read references of religious material, as well as as a means to store the propagation material which subsequently submitted during the recitation. The last is to make use of the existing apps in their devices to recall verses or hadiths that happen to be forgotten when delivering lecture materials. The mubalig rate, technology and social media are something positive to use as a medium of preaching communication. Thus, mubalig are not allergic to technology and social media, even some of them become active users in social media. Similarly, in his own devices, there are many applications of the Qur'an and Hadith. Carrying a device is an effective way of learning, carrying the reference of the book, because mubaligh does not have to bring a physically large book when doing preachings to various places and locations. Technology is considered to be able to connect them with the other ustaz, kiai or religious figures in the same or different organizations.
\end{abstract}

\section{Keywords:}

Technology, communication, Al-Quran-hadith, mubalig. 


\section{Introduction}

Science and technology have an urgency in the Qur'an and hadith to be constantly applied in human life. The Qur'an does not directly provide a text that is clearly related to science and technology, so that human beings whom Alloh SWT make to be intelligible to understand the verses of the Qur'an can get it. The first sura that Allah revealed to Prophet Muhammad SAW is a manifestation of our obligations as human beings, servants of God to always read (understand) what is in nature. The many verses of the Qur'an that describes the phenomenon of nature, requires that humans always do deepening, and the Qur'an explains that understanding the phenomenon of nature means also understand the sign of the power of Allah SWT. In fact, many Quranic readings are based on natural phenomena to understand the essence of God, one of which is the Sufistic path of looking at natural phenomena as a sign of God's essences. God, Man and Nature are interconnected triangles according to Sufi interpretation. (Putra 2018: 185).

Sura that indirectly demands to always investigate the natural phenomena, is surah al'Alaq 1-5: "Read by (call) the name of your Lord Who Creates. He created man from a clot of blood. Read and your Lord Most Gracious. The Teaching (buman) through the mediation of kalam (write read). He taught man what he did not know". The word iqra is derived from the root of the word which means that it brings together many meanings such as conveying, studying, exploring, researching, knowing something. The first verse that is revealed must be the basis of thought (qaidah fikriyab) by man, so that all the buildings of thought and knowledge must be by faith in God (E 2017: 70).

It highlights the importance of mankind, especially Muslims in developing science and technology in order to realize the three goals of the realization of a state that has an intelligent society, prospering the life of the people and most importantly Islamic religious teachings. Applying

DINIKA, Volume 4, Number I, January - April 2019 
science and technology in accordance with the content of Islamic teachings as a means of getting closer to God. In fact, the development of sciencebased Qur'an always continues to be developed to bring people closer to the Qur'an through technology (A and U.J 2013: 1).

The Qur'an also described some process in seeking the application of science and technology tradition that is in Surah Alghasiyah verses 1720: "So whether they do not pay attention to the camel, how it was created. And the sky bow he was lifted. And the mountains how to uphold. and the earth how to spread". The importance of paying close attention to in a broad sense is related to the phenomena that occur around. For instance, sub-Surah Alqamar verse 149: "We created everything by measure" emphasizes that man must make measurements of all the natural phenomena that occur (J 2010: 8-9).

The importance of technology and science in the Qur'an and hadith, is not only limited to the conceptual contained in the Qur'anic verse, but also related to the application of technology to everyday human life. It can be seen from some activities and activities conducted by Muslim scientists. To mention one example, what is done by the Ministry of Religious Affairs of Central Kalimantan by holding training on the development of $\mathrm{Al}$ Quran and Hadith based on Informatics technology and e-Book Libraries in Palangkaraya City in STAIN Hall Palangka Raya ("Development of AlQuran and Hadist-Based Technology" 2018).

The use of technology in Islamic da'wa massively happened. Thus, it became a new form of religious involvement in Indonesian public sphere. This phenomenon has occurred at all levels of society, states, mass organizations, even at the individual level. Muballig used certain applications for spreading Islamic da'wa, such as the one carried out by Abdullah Gymnastiar or the so-called Aa Gym. The Application so-called 'The Aa Gym app' describes how the Indonesian Islam rising Islamic teachings through mobile technologies media. (Fakhruroji 2019: 201) 
According to Zulhazmi and Hastuti, the characteristic of millennial generation that tend to think out of the box and is always connected to the internet have changed the landscape of da'wa in Indonesia. They slowly leave the conventional da'wa both in terms of topics and methods as reflected by the growing popularity of da'wa style practiced by preachers such as Hannan Attaki. Social media gives positive contributions for the practice of da'wa even though it can also bring negative consequences such as the emergence of artificial da'wa, unfinished da'wa, and the proliferation of hate speech in the name of da'wa. Muslim consumers of online da'wa are also enticed to leave the main Islamic teachings references for instant teachings available of internet. (Zulhazmi and Hastuti 2018). It related to Halim opinion that the existence of the internet raises many opportunities and challenges. The Society becomes easy to interact with the Quran independently and understanding of the Quran freely becomes easily spread with a lack of control in addition to the obstacles of understanding also found. (Halim 2018).

In mass organization level, technology has been applied in da'wa activity of Islamic organization in Indonesia permanently. One of them is done by Council of Da'wa Indonesia (DII) and Ikatan Mesjid Indonesia (IKMI) by implementing web service and service oriented architecture (SOA). The application of such technology was made to facilitate the performance of the Indonesian Da'wa Council (DII) and the Ikatan Mesjid Indonesia (IKMI) in coordination with the preachers in filling the Friday sermon and the recitation instructors (I and N 2014: 1)

This research used qualitative descriptive approach by photographing the phenomenon that occurs in the Ulama and muballigh who carry out da'wa activities. The method of data collection was done through observation directly (observasition) to the activities of ustad and muballigh when doing da'wa in various places of worship, mosolla mosque and others. The researchers also conducted in-depth interviews with the directly related 
informants, muballighs who are members of religious mass organizations, starting from Nahdlatul Ulama (NU) Muhammadiyah, Persatuan Islam (Persis), Ikatan Dai Indonesia (IKADI) and muballigh who is not affiliated with Islamic mass organizations. This study lasts for approximately one month, starting mid-May to mid-June 2018. The results of the interview and then followed up by re-checking a number of accounts belonging to the clergy and muballigh that exist in social media, such as what social media the cleric is using for the dissemination activities of the Qur'an and Hadith, whether it is submitted at the time of the interview or not so that this research is sufficient to produce a research with comprehensive results to photograph the phenomenon that occurred.

Mass communication is a form of communication that is instant and massive. A number of experts give insight into mass communication. Soyomukti's conscience, for example, gives a sense of mass communication by calling a process, the place of a complex organization with the help of one or more machines producing and transmitting messages to a large, heterogeneous, and dispersed audience (N 2012: 192).

Some other experts also define the notion of mass communication. Bittner defines mass communication as a message communicated through mass media, which is not to a few people or one person, but to a large number of people (K 2016: 1).

Mass communication has characteristics and uniqueness in which interpersonal communication does not happen. Among the characteristics of mass communication is, it is general. In this context Mass communication is open, meaning that it is for everyone and not a group. Messages can be facts, events, or opinions but they must have an important or interesting element (M.U 2017: 68).

In addition, mass communication is anonymous and heterogeneous. Communicators and communicants in mass communication may not be know each other (anonymous), but there could also know each other, 
because the media as an intermediary of communication. Communicant in mass communication is also heterogeneous because it can be grouped from various layers of society, not only occur in certain groups only (A.K 2016: 81-82).

Mass communication gives rise to simultaneity. The number of target audience or communicant relatively many and unlimited and the many communicants simultaneously at the same time get the same message. Both the time and the message received can be simultaneous, or simultaneously (H. A 2005: 22-25).

Mass communication is one way. One of the weakness of mass communication that is one way, which means between communicator and communicant does not occur direct contact. But in some cases mass communication also takes place in two directions, meaning there is interaction between communicator with communicant like in radio and television in interactive dialog (W 2006: 17-20)

\section{Social Media and the Spreading of Quran and Hadith}

The existence of technology that is so advanced today, becomes part of human life, including in religious life. No matter how small, the whole joint of human life has undergone a touch of technology. Between life and technology, in the modern era, the two sides of the currency can not be separated, and always interrelated. People can no longer avoid technology. Changing times affect the development of increasingly sophisticated technology and enter in every aspect of human life, including aspects of religious life. This also becomes a challenge for the spread of Islamic da'wa. (Hasan 2019: 230). The influence of technological developments for the spread of Islam, for example, can be seen in smartphone applications (smartphones) that can be used as a medium of worship, such as the Quran application and call to prayer. The existence of the application certainly makes it easier for humans who want to always be close to Allah SWT.

DINIKA, Volume 4, Number I, January - April 2019 
Basically, the function of information technology in cyberspace is the direct participation of the masses in conducting the communication process. So, the communication model formed by cyberspace is mass communication that involves many humans in its process. In other words, communication becomes the material while the virtual world becomes a medium or media. This will be a suitable partner in spreading da'wa through information technology.

The effectiveness is one of the advantages of information technology. This is caused by the sophistication of information technology that has succeeded in erasing geographical space in human life so that its existence feels very important to human life and has become a vital need for the life of contemporary society. This situation should be an extraordinary opportunity for the scholars to spread propaganda information throughout the universe across countries and languages quickly. The era of acceleration of information technology does not always have a negative meaning. The existence of information technology can be interpreted as an opportunity to carry out a comprehensive da'wa.

Religious programs and activities, including Ulama and muballighs engaged in da'wa activities to convey the Qur'an and Hadith, always use technology as part of the means to meet the needs in performing religious duties, both for the purposes of communicatingwith pilgrims of recitation, to read references and religious materials, as well as a means to store the material which was then delivered during the recitation.The MUI da'wa application that can be accessed on mobile phones to support of the preaching in this millennial era. Through this application as a da'wa map, the da'i are given information about the problems of another da' $i$ in the area to be preached (mad'u).

As is commonly done by the ustad and muballigh who came from various Islamic organizations in Indonesia, including Ulama and muballigh who are not affiliated to a particular Islamic organization, they continue 
to make technology a part of the need to spread the Qur'an and Hadith. As stated by Ustad Amirullah, one of the muballigh of Persatuan Islam (Persis). Ustad Amirullah claims to be a user of the device in which there are several applications of the Qur'an and hadith, such as the Hadith Encyclopedia, the application of Hajj and Umrah, the application of ruqyah verses, and murrotal applications. During the use of existing applications in the device, he admitted that he greatly benefits from it. Like the use of the Hadith Encyclopedia, by simply typing a keyword, some Hadiths will show up related to the topic to be conveyed. By using the application of the Qur'an, he can also know the limits in doing recitations. The application makes it simpler to do the da'wa since they do not have to carry a large bag with a heavy book. This application has proven to be effective. Even so, Ustad Amir claimed that he often uses the application in the device to deliver material da'wa especially in urban communities who are aware of technology. For the people in the countryside, he admitted that he avoids the use of the device, because in the village if the cleric opened a notebook let alone a device, he will be considered as not mastering the material presented ${ }^{1}$.The da'i and muballig can make social media as a da'wa channel and build a da'wa strategy through that channel so that the symbols of Islam can be conveyed properly.

The same thing was stated by Ustad Ahmad Yasin, one of the Muhammadiyah muballigh. Ustad Yasin claimed to have been very familiar with the technology that stores religious applications such as radios that usually broadcast religious materials such as lecture at dawn or for the purposes of monitoring the listener as a resource person on the radio interactively. In addition, other applications that exist in Ustad Yasin's tool is an application to wake up tahajud prayer².

1 Interview Ustad Amirullah in Al-Hidayah Mosque, 2 June, 2018.

2 Interview Ustad Ahmad Yasin in Darussalam Mosque, 1 June, 2018.

DINIKA, Volume 4, Number I, January - April 2019 
Ustad Kiky who is a muballigh of Nahdlatul Ulama (NU) claimed to be very familiar with the gameplay and other technologies. This ustad claimed to use technology as a source to explore existing religious information and as a means to communicate and stay in touch with fellow ustad, as well as with pilgrims and ummah. To Ustad Kiky, the device became one of his reading materials. Through the tool, he surfs in Google search engine to get the needs of science and materials propaganda to be conveyed to the ummah and pilgrims who scouted ${ }^{3}$.

The same thing goes to Ustad Insan, one of the muballigh who is not affiliated to the existing Islamic mass organizations. Ustad Insan claimed to have benefited a lot from using the device and social media. Common devices are used for communication purposes, and search for the latest information that is scientific in nature. To make it easier to access various information and science, this ustad enter a number of applications of al-Qur'an and some Hadith books in his own devices ${ }^{4}$.

Ustad Ilham Mahmi, one of the muballigh Persatuan Islam (Persis) felt the great benefits of the advancement of the existing technology. He claimed that the existence of technology in the application of the Qur'an and Hadith in his own gameplay are very helpful. According to him, with the application in the device, he no longer needs to bring here the physical form of the Qur'an, because in the device, the friction has already appeared and can be read. The application of the Qur'an in the device also facilitates him in delivering religious lecture material from the Qur'an and Hadith, because he felt that he is a person who is not realy fast in memorizing the arguments of the Qur'an and Hadith so that the existence of the application is in great help ${ }^{5}$.

3 Interview Ustad Kiky in his home, 3 June, 2018.

4 Interview Ustad Insan in his home, 4 June, 2018.

5 Interview Ustad Ilham Mahmi in Baitul Arham Mosque, 20 May, 2018. 
In addition to being familiar with technology using the device, the cleric and muballigh turned out to be active social media users. One of the muballigh Persatuan Islam (Persis), Ustad Amirullah claimed to have used social media since five years ago. He considered, social media is an effective communication medium today. Through social media, communicating with many parties can be easier. Ustad Amir is very familiar with almost all social media, ranging from Whatsapp, Facebook, Twitter, Istagram, Telegram and Youtube. In the social media that he uses, he admitted that there are many needs which can be met. Through Whatsap, he can get information or propagation material within the group of dai joining in it. On Facebook and TwitterAs well, he can establish communication with fellow alumni on campus, or long-distance friends despite the distance, communication becomes easier to $\mathrm{do}^{6}$.

Another Mubalig from Muhammadiyah, Ustad Ahmad Yasin claimed to have used social media in the last three years, but only limited to Whatshap and Youtube only. According to Ustad Yasin, social media is an effective medium today. With the presence of Whatsapp, he can communicate with the Muhammadiyah community throughout Indonesia. From there, he also received propagation materials within Muhammadiyah groups, so that it can enrich the insight and language used for preaching. Besides via Whatsapp, he can also send a video clip of religious lectures to his congregation. As on Youtube, Ustad Yasin claimed to use it to watch the da'wa video of national muballigh, such as Ustad Somad and others, as well as a reference to be da'wa material ${ }^{7}$.

In contrast to other religious and religious leaders, Ustad Mudhar Beek, a member of Ikatan Dai Indonesia (Ikadi), admitted that he did not use the device or social media. Although he does not use the device, he sees the device as a means or medium to speed up the message of da'wa.

6 Interview Ustad Amirullah in Al-Hidayah Mosque, 2 June, 2018.

7 Interview Ustad Ahmad Yasin in Darussalam Mosque, 1 June, 2018.

DINIKA, Volume 4, Number I, January - April 2019 
Technology in the form of various applications in the device will also facilitate people who receive da'wa messages to convey and disseminate to others. According to him, the Prophet Muhammad SAW as the closing of the prophets and apostles, so that no more prophets and apostles after him. While propaganda of the prophets, from the Prophet Adam AS, to Prophet Muhammad SAW, and will continue to continue until the Day of Judgment, the technological sophistication becomes one of the forms of da'wa media that will continue to benefit the ummah ${ }^{8}$.

If viewed more closely, social media that has been accessed by the mubalig for various purposes, including communicating the real part of the practice of mass communication. Although sometimes social media is personal, but gradually and slowly, it can shift the role and existence of mainstream media, caused by the process, as if the mass media has become traditional.

This is because more material is partly needed by audience, but not in the mainstream media. Audience feels the need and the need for information, material and news submitted by people who deliver messages on social media (S 2014: 256).

Mubalig as a communicator in conveying the message of da'wa to the congregation, Muslims who become communicant can not be separated from existing technology and social media. As a communicator, the function of mubalig is of course quite significant in influencing the thoughts, attitudes, behaviors and acts of religious congregation or ummah. it also will definitely impact massive alterations because the process of conveying the message is no longer solely determined by time such as the recitation time, as well as the Friday sermon time, it is not limited by certain places, but much more extensive and flexible. Anytime and anywhere mubalig can convey a message of da'wa to the people and their congregation. The presence of religious leaders as religious

8 Interview Ustad Mudhar Beek in his house, 25 May, 2018. 
leaders, who have been considered to have the ability and authority to convey religious messages, make pilgrims and people believe in mubaligs who convey religious messages, either directly or through social media. Beliefs arising from such communication are more powerful in changing the mindset and actions of the congregation and people. Especially, if the communication is delivered through a very intensive and interactive between mubalig and the congregation. Moreover, it is very possible with the progress of information technology and social media that has been so advanced and personal.

Da'wa behavior using technology and social media does not occur randomly or accidentally. This movement occurs structured and collectively carried out by muballig with certain organizational backgrounds. Mass organizations in Indonesia such as NU, Muhammadiyah, Persis, DII, and Tarbiyah instructed their muballig to change their missionary mission from conventional to digital media-based da'wa. (Ahmad 2014: 319)

The da'wa concentration of mass organizations in Indonesia on the use of digital technology was carried out simultaneously. This concentration is based on a collective awareness of the effectiveness of da'wa in an era that is instant, global and based on information and data. Muhammadiyah, NU, Persis, MUI, Ikadi, and Tarbiyah moved to give special attention in welcoming digital da'wa with various innovations, creativity and ideas.

Mass organizations pay attention to efforts to interpret the Quran in social contexts using the digital media. The contextualization of the Quran and the hadith is disseminated massively and systematically. In addition, the mass organization is believed to targeting middle class as a da'wa object. It is due to the middle class da'wa which seems to be a challenge of the organization of the second century and that second century was filled with the modernity and the rapid advancement of information and technology.

DINIKA, Volume 4, Number I, January - April 2019 
Portraits of mass organization da'wa for the Moslem society require a new approach. They are very attached to information and technology and the progress of the times. Therefore, the variety of approaches also needs to be included in the niche of contemporary da'wa.

Nevertheless, this joint instruction still brings the identities of each mass organization. The da'wa of Muhammadiyah for example on amar ma'ruf nabi munkar, encourages the process of awareness and alignment of the Muhammadiyah to the muslim society growing-phenomenon. It is has a relatively well-educated economy, but their ideology tends to be fragile. (Ali and Purwadi 2017: 12).

This digital da'wa becomes the hallmark of Muhammadiyah in its da'wa approach. Digital da'wa needs to read the phenomenon of people who want to be instant but still fashionable. Society wants a practical, but meaningful Islam. This meaningfulness is often missing from the Muslim society. People in the globalization and digital era want to be seen as fashionable and practical, but do not have a strong foothold. This fashionable da'wa is a hallmark of Da'wa in the digital era, the aim being to harmonize religious content with the invention of style in da'wa. (Fakhruroji 2017: 201).

Muhammadiyah prepares a set of tools to color the religious life that society gets from the media. Muhammadiyah's web sites continue to actively voice Progress Islam so that they get balanced information about religious understanding.

Muhammadiyah's website and da'wa channels organized by Persyarikatan activists founded by Kiai Haji Ahmad Dahlan need to be actively voiced. They voiced Progressing Islam as the core of the Muhammadiyah missionary movement. The active voice of Muhammadiyah will be able to stem the flow of conservatism that is increasingly massive into the joints of the lives of the middle class. 
The moslem society needs to be given an alternative da'wa approach so that they are able to implement religion and they contemporary life. The Voice of digital da'wa is projected as a "backflow" of conservative da'wa media. As a stream of rivalry and alternative media that will become the mainstream, Muhammadiyah needs to strengthen the power base that supports this missionary movement.

In other side, NU gives more attention to digital da'wa in terms of the orientation of the preaching material. NU tries to build digital da'wa content in terms of religious studies from authoritative sources according to NU. This is because millennial generation shows a high enthusiasm to study religion. However, this spirit can be disoriented if it fails to understand the essence of religion properly. NU believes that the phenomenon of studying religion through the internet also gave rise to instant generations in understanding religion, ffor example, studying religion through non-authoritative and non-contextual translation of religious books. Consequently, the millennial generation cannot understand religious phenomena properly and correctly.

NU tries to encourage religious literacy sourced from teachers and reference books which will clearly strengthen the religious understanding of the younger generation. NU is known as a cultural organization based on Muslim lay people or is called a traditionalist society. (Razi 2011: 163). These characteristics provide a different orientation in NU-style digital da'wa. NU is traditionalism in the sense of the Islamic movement which has traditional self-awareness (self-consciousness traditionalism). This means that NU residents are Muslims who are aware of tradition, making tradition a "symbolic filter" to interpret something. Even more than that, tradition is placed as a quasi-ideology (which is open), dealing with other ideologies.

In line with NU or Muhammadiyah da'wa approach, development of digital da'wa according to Persis to tidy up unity of Moslem society so 
that da'wa is carried out to touch all societies. Persis assesses that Dai and muballig, must have a broad understanding and insight about information technology and social media to be able to preach using information technology channels in accordance with the regulation of the internet. In carrying out this mission, Persis provides an understanding of cyber law that must be followed by every preacher who runs digital propaganda.

Persis has been carrying out digital da'wa through the PersisTV channel on YouTube and the official website of the organization. The dynamics of the Persis da'wa became an opportunity in the digital age because through digital message, da'wa can be more diverse and reach out to many people effectively. In addition, comprehensive knowledge is considered important for Persis members for the integrity of the people and nation. This marks the transformation of the current preaching from the exclusive to the inclusive. In education, changes in da'wa are not only from the pulpit to the pulpit, but can be wider through social media and digital video.

Through material perspective and da'wa content, digital da'wa is used to distribute content and published Quran and hadith on themes that are suitable for plural Indonesian society. The teachings of the Quran and the hadith are distributed by all organizations in the same principal; usually the verses relating to social humanity. Neither the hadiths taught are hadiths that confirm the message of peace, tolerance, brotherhood and harmony. Verses that are always concentrated on digital da'wa in Indonesia are the problems of interfaith relations al-Kafirun: 6, at-Taubah: 128, and surah Ali Imron verse 104. The interpretation of these verses becomes important due to the diversity of religions in Indonesia. NU through the cultural Islamic platform understands verse 109: 6 as a verse that maintains the social harmony of the community from theological clashes. The interpretation of the Sufi Al-Kafirun above is to educate the Muslim desires to act tafrit and ifrat in worship. Based on the asbabun nuzul alKafirun Sura, the NU views this verse as a verse of religious tolerance. 
The basic principle of the verse and asbabun nuzul of surah Surat al-Kafirun has become one of the foundations of religious tolerance which was exemplified by the Prophet Muhammad since 14 centuries ago. The asbabun nuzul surah Surat al-Kafirun has become an example of the Prophet Muhammad to behave with non-Muslims, and is still relevant to be applied today. However, it must be accompanied by contextualization that does not conflict with Islamic values.

Muhammadiyah also paid attention to the da'wa material related to religious tolerance. Verse 109: 6 is a perfect representation as a common thread of religious tolerance in a heterogeneous society (Taher 1998: 52). Muhammadiyah even emphasizes the concept of al-Washatiyah as maintaining harmony and harmony among religious communities.

Similarly, Persis also used verse 109: 6 to build harmony in interreligious relations. However, Persis has two different interpretations of the verse from other organizations; firstly, the difference in the meaning of ma'bud (the difference that is worshiped), and second, the difference in kaifyat (differences in procedure). Persis underlines that that verse 109: 6 does not regulate intra-religious relations. According to Persis, the intrareligious relations are regulated in the verse at-Tawbah: 128 and Ali Imran: 104. Both verses emphasize that the intra-religious relationship must be built with the concept of partnership in order to maintain and advise one another. (Rismawati 2018: 20).

NU, Muhammadiyah, Persis, MUI agreed to increase the flow of alWasatiyah in Indonesian Internet content (Putra 2019: 3) Submission of religious information must be directed to enlarge the space for moderation of the community and reduce extreme and liberal discourse in religion. According to Scott M. Thomas, radicalism in religion will lead to acts of violence and social terrorism (Thomas 2005: 24). Mainstreaming the teaching of the Quran and hadith in digital media refers to the religious characteristics of each organization.

DINIKA, Volume 4, Number I, January - April 2019 
The characteristics of each mass organization influence the pattern of communication of their respective digital da'wa. In the phenomenon of the Islamic world, Indonesia has various cultural powers. The formation, among others, is through organizational groupings, such as NU, Muhammadiyah, Persis, LDII, Tarbiyah. Each grouping brings a unique representation and membership of the Islamic culture. When explained, each of them represents certain Islamic experiences, backgrounds, social values and expectations. Each Islamic culture of each group brings diversity of Islamic group colors. Each is different. Each subculture of Islamic groups has a different pattern of perception of community behavior.

From this, it is clearly that there is a culture that influences Muslimgroup communication behavior. Their perception and communication behavior of the Islamic groups is formed in the process and cultural interaction of certain Islamic groups. All forms of Islamic communication between their groups are based on the "response and function" process of how Islamic culture moves around them; the response to the Islamic culture that burst around them. They make use of the potential of Islamic culture in Indonesia, through the perception of the subcultures they frame, for their respective goals and interests. As the result, we can see the differences between Persis and NU in communicating, bringing certain dimensions of interest, in the Islamic mosaic in Indonesia.

\section{Conclusion}

Technology and social media is the development of science which, although accepted, can no longer be rejected. This is happening to the mubalig in Indonesia, they do not reject the existence of technology that is more advanced and growing. Even among existing mubalig, utilizing technology and social media to support the needs ofda'wa and learning religion. So far, they are also very active using social media to communicate with fellow mubalig in one organization, as well as with mubalig in other 
organizations. They mostly use it to communicate with the congregation, both personally and group by sending massive and simultaneous religious messages. It is necessary for the government in this case the Ministry of Religious Affairs of the Republic of Indonesia with the Majelis Ulama Indonesia (MUI) and religious organizations in Indonesia such as Nahdlatul Ulama (NU), Muhammadiyah, Persatuan Islam (Persis) Al-Irsyad, Da’wa Islamiyah Indonesia (DDII) Al-Khairat,Jamiatul Khair, and others to sit together to make a kind of syllabus and religious propagation material distributed regularly every day or week to the preachers through specially tailored social media and technological devices, and able to reach out to the preachers from all overexisting Islamic organizations. Thus, hopefully, the material of the delivered propagation which is the content of the Qur'an and the hadith of the Prophet can simultaneously have in common so that the content of da'wa accepted by Muslims will also be closer together. Otherwise, the mubalig will seek references and propagation material himself, which then being submitted to the congregation and the ummah, in accordance with what is obtained in social media through technology that has increasingly personal nature.

Digital da'wa is a necessity that is demanded by the development of society. Digital da'wa is used simultaneously and massively by mass organizations in Indonesia in spreading the Quran and hadith. Muhammadiyah uses digital da'wa as a way to show a fashionable da'wa display. NU uses digital da'wa to reintroduce Islamic traditions. Meanwhile, Persis using it to ensure that the society enjoys the da'wa of Islam. On the other aspect, all Islamic organizations agreed to disseminate content aimed at strengthening the social community of Muslims. They pay more attention to the verses of the Quran and hadith that are related to tolerance, peace, tolerance, brotherhood and harmony. They also reinterpret verses related to these themes by contextualizing verses in Indonesian people's lives, like verse al-Kafirun: 6, al-Tawbah: 128, and ali Imran: 124.

DINIKA, Volume 4, Number I, January - April 2019 


\section{References}

A.K, Riva'i. 2016. Social Communication Development: A Review of Communication Theory In Social Development. Pekanbaru: Eve and Ahwa.

A, Hadi. 2005. Death of Cyberspace World: Human Slouka's Markish Criticism Against the Mayan Universe. Yogyakarta: LKiS Yogyakarta.

A, Priyatna, and Basuki U.J. 2013. "Development of Multimedia-Based Multimedia Based Learning Application." Journal of SCRIPT 1 (1): 1.

Ahmad, Nur. 2014. “Tantangan Dakwah Di Era Teknologi Dan Informasi: Formulasi Karakteristik, Popularitas, Dan Materi Di Jalan Dakwah." ADDIN 8 (2).

Ali, Hasanuddin, and Lilik Purwadi. 2017. Indonesia Middle Class Muslim: Religiousity and Consumerism. Jakarta: PT Alvara Strategi Indonesia.

"Development of Al-Quran and Hadist-Based Technology." 2018. Kemenag.go.id. 2018.

E, Iryani. 2017. "Al-Quran and Science." Journal of Scientific Batanghari University Jambi 17 (3): 70.

Fakhruroji, Moch. 2017. "Religiously Fashionable: Constructing Identity of Urban Muslimah in Indonesia." Jurnal Komunikasi: Malaysian Journal of Communication 33 (1): 199-211. https://doi.org/https:// doi.org/10.17576/JKMJC-2017-3301-14.

_. 2019. "Digitalizing Islamic Lectures: Islamic Apps and Religious Engagement in Contemporary Indonesia." Contemporary Islam 13 (2): 201-15. https://doi.org/10.1007/s11562-018-0427-9.

Halim, Abd. 2018. Wajah Al-Quran Di Era Digital. Edited by Lutfi Rahmatullah. Yogyakarta: Penerbit Sulur.

Hasan, Hadri. 2019. "Contemporary Religious Movement in Indonesia; A Study of Hijrah Festival in Jakarta in 2018." Journal of Indonesian Islam 13 (1): 15-30. https://doi.org/10.15642/JIIS.2019.13.1.230265.

I, Iskandar, and Jannah N. 2014. "Service Oriented Architecture Analysis (SOA) Uses Web Services for Scheduling Mubalig on IKMI and DDI." SiTekIn: Journal of Industrial Science and Technology 11 (1): 1. 
J, Fakhri. 2010. "Science and Technology In the Quran and Its Implications In Learning." Journal of TA'DIB 15 (1): 8-9.

K, Romli. 2016. Mass Communication. Jakarta: PT Grasindo.

M.U, Sukendar. 2017. Communication Psychology: Theory and Practice. Yogyakarta: Deepublish.

N, Soyomukti. 2012. Introduction to Communication Studies. Yogyakarta: ArRuzz Media.

Putra, D.I. Ansusa. 2018. "Epistemologi Tafsir Sufi Perspektif EsoterikFenomenologi." Jurnal Ulul Albab 19 (2): 185-208. https://doi. org/10.18860/ua.v19i2.5019.

. 2019. "Interpreting Al-Wasathiyah in Digital Era: Tracing the Contribution of the Al-Azhar Alumni in Indonesia Public Sphere." In Presented at International Conferece of Islam and Muslim Society (ICONIS, LAIN Salatiga).

Razi, Fahrur. 2011. "NU Dan Kontinuitas Dakwah Kultural." Jurnal Komunikasi Islam 1 (2).

Rismawati, Alfie. 2018. "Penafsiran Ayat-Ayat Toleransi Menurut Ormas Islam (NU Dan Persis) Jawa Barat.” UIN Bandung.

S, Shah. 2014. Discussing the Press, Head of State and Media Ethics. Jakarta: PT Elex Media Komputindo.

Taher, Tarmizi. 1998. Menuju Ummatan Wasathan: Kerukunan Beragama Di Indonesia. Ciputat: PPIM IAIN Jakarta.

Thomas, Scott M. 2005. The Global Resurgence of Religion and the Transformation of International Relation. New York: Palgrave Macmillan.

W, Wibowo. 2006. Brave Writing Articles, New Round Article Writing Tips for Mass Media Print. Jakarta: Gramedia.

Zulhazmi, Abraham Zakky, and Dewi Ayu Sri Hastuti. 2018. "Da'wa, Muslim Millennials and Social Media." Lentera II (2).

DINIKA, Volume 4, Number I, January - April 2019 